\title{
Advances in Modern Nigerian Art and Urban Aesthetics: Osogbo Fence Beautification's Experience
}

\author{
ABEJIDE, Foluso Modupe \\ Department of Fine and Applied Arts, Obafemi Awolowo University, Ile-Ife, Osun-State
}

\begin{abstract}
Fences and boundary demarcations are later additions to buildings, for fortification, while their ornamentation is an advancement in modern Nigerian art from the 1970s. Studies of wall decorations have focused mainly on facades of buildings and shrine walls, with little scope for ornamentations on fences of private residential buildings. This study investigates the trends in boundary demarcation in Yoruba culture, highlighting the innovations in the practice. It also classifies the forms and styles in the decoration on fences of domestic buildings, using Osogbo, a prominent city in the advancement in art and culture, since its inception. The study reveals rich and divergent styles of artistic embellishment in fences of private homes, in diverse materials. The ornamentation on fences are observed to evolve with the means of the owners and indirectly enhance the aesthetic of the environment.
\end{abstract}

Keywords: Fence beautification, Fortification, Modern art, Urban Aesthetics, Osogbo.

DOI: $10.7176 /$ RHSS/10-4-01

Publication date: February $29^{\text {th }} 2020$

\section{Introduction}

Beautification is the art of ornamenting or enhancing visual appeal. Osasona (2005:1-2) defines ornamentation as the process of embellishing features of works or adding features for decorative purposes, which is aptly described as a means of beautifying man's dwelling, making it aesthetically pleasing. Art in the context of architecture is a tool in beautifying and distinguishing both the houses and the living environments. The use of art for beautification, and transformation of the environment had been since the pre-historic times, with variations in styles, locations, forms and materials. Hence, there had been diverse art forms in buildings. Ornamentations of fences are advances in locations of ornamentation of buildings, and new developments in modern Nigerian art.

\section{Literature review}

Literature abound on fences of residential buildings, some studies highlight the causes and effects of erected fences in private residences (Roitman. 2010 and Torrington, 2013), while many focus on the transformations of fortifications as a reaction to crime in cities globally (Landman \& Schonteich, 2002; Atkinson \& Blandy, 2005; Anokye et. al 2013). Others look at fences as a product of social inequality, which facilitate urban insecurity and segregation (Manzi \& Smith-Bowers, 2005; Ilesanmi, 2012; Torington, 2013). Fadamiro et. al (2015) soutriedght to determine the best social-mix in housing development to alleviate the urban insecurity ensuing from residential fencing. Osasona (2006:35-46) however delved into the history, functions and materials of fortresses, highlighting the traditional roles of fence walls as containment of domesticated animals and its advancement as architectural accessory. It further classified, and showcased decorative arrangements of stucco fence architecture in Nigeria, affirming that it has become highly-elaborated aspect of Nigerian architectural practice, that account for as much as $20 \%$ of architecture project cost. This study in addition to classifying the types of fences in Osogbo, builds on Osasona's expositions on stucco fences, while further highlighting the advancements in fencing barriers, after Osasona's study, most especially the new trends in artistic embellishment of fences.

\section{Research Methodology}

The study utilizes both primary and secondary sources. The primary data were obtained through field investigation, physical observation and photographic survey of domestic buildings with uniquely ornamented fences in Osogbo, sourced through the referral snowball technique (RDS). They were utilized in the identification of types of fortification walls and their decorations. Secondary data from relevant literature were used to supplement the primary data. The study population is considered to be limitless due to the immense number of reliable current data on buildings with ornamented fences in the study area. However, thirteen (14) varied fences in Osogbo city were purposively selected for case study. They are examined based on their uniqueness, advancement in their forms and variation in the materials used. The data was analysed using descriptive means.

\section{The Origin of the Use of Fences in Osogbo}

Before the colonial period, there was no need for fencing Yoruba houses and compounds, because border used to be marked with plants. Prominent plants for this purpose were pèrègún (Dracaena Fragrans), làpálàpá or botuje (Jatropha Curcas Pysic) and botuje-pupa (Jatropha Gossy piifolia), (Abraham, 1958:552). Osasona (2006:37) records the use of shrubs with dense foliage, barbwire and earth fences; however, the known forerunners of modern 
fences were the low wall of about 4 feet, which enclosed paved foreyard of Afro-Brazilian buildings (Figure 1). They were often embellished with concrete balustrades. The elaboration of the low walls with figurative representation in Osogbo, is traceable to Suzanne Wenger's innovative use of cement screens for boundary demarcation, in the 1950s, and her work in the Osun groove (Figure 2).

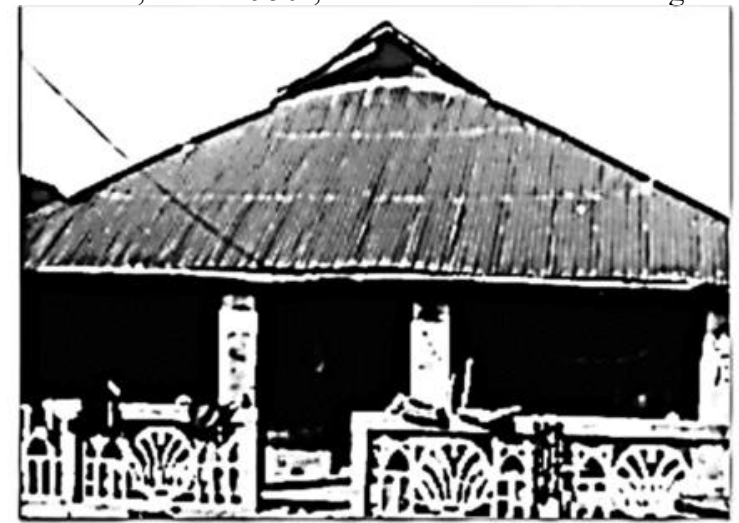

Figure 1: The paved foreyard of an Afro-Brazilian building in Gbomi, (Photo: F.M. Abejide, 2019).

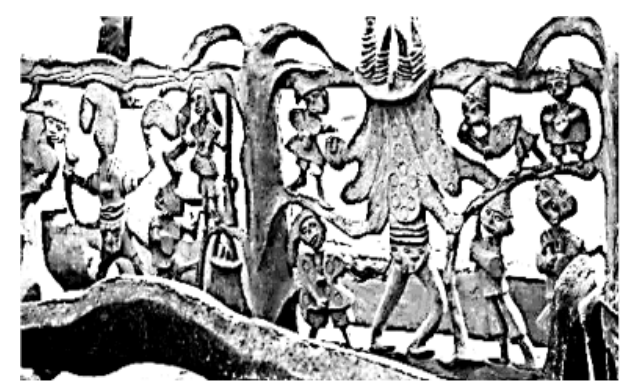

Figure 2: Wenger's stucco screened Osogbo, boundary Demarcator (Photo: F.M. Abejide, 2019).

\section{Factors That Led to the Use of Fences}

Insecurity ensuing from the Biafran war, the absconding of many armed soldiers from the both the Nigerian and the Biafran sides during the war, and the disengagement of many of the soldiers after the war from 1970, with or without relieving them of their ammunitions, opened the country to robbery incidences (Marenin and Reisig, 1995:503). This was aided by the discovery of crude oil in Nigeria in the late 1960s and its boom from the early 1970s, which improved the nation's economy (Siollum, 2009: 168). This led to a bonus award of special salary increment to all civil servants by the Gowon administration, in January 1975, (recommended by Chief Jerome Oputa Udoji's committee). The sudden wealth, abundance and indulgences from the "Udoji award" (as it was tagged), led to affluence, buying of luxury goods (Obijiofor, 2008), while the ensuing increase in purchasing power led to changes in styles and ornamentations of domestic buildings to reflect the opulence. Udoji was the beginning of the classification into low, medium, and high density areas, with increase in ornamentation tendencies and fortification commensurate with the locations. The hyper-inflation as well as the wide gap between the rich and the poor, ensuing from Udoji, further resulted in an increase in violent crimes, in the early 1970s. Incidences of robbery and the need for procurement of additional security necessitated the building of gated fences to keep away intruders.

\section{Types of Fencing Barriers in Osogbo}

At its inception, fencing barriers were made with low concrete walls of about 6 feet (or lower), built with granite or sandcrete blocks. There are many types of ornamented fences in Osogbo. They can be classified as fence walls in designed perforated masonry blocks, fences decorated with ceramic bricks, structurally designed fences, fence ornamentation in stucco reliefs, paint embellished fence walls, ornamented fences in mud reliefs or stabilized earth, and fences in contemporary add-ons.

\subsection{Fences in Perforated Masonry Blocks}

The early low concrete demarcation walls used to be topped with perforated masonry blocks or reinforced concrete balustrades for visibility (Figure 3), with connection points between two walls reinforced with iron pillars. However after the foundation blocks, the entire wall used to sometimes be erected with network of perforation blocks (Figure 4). 


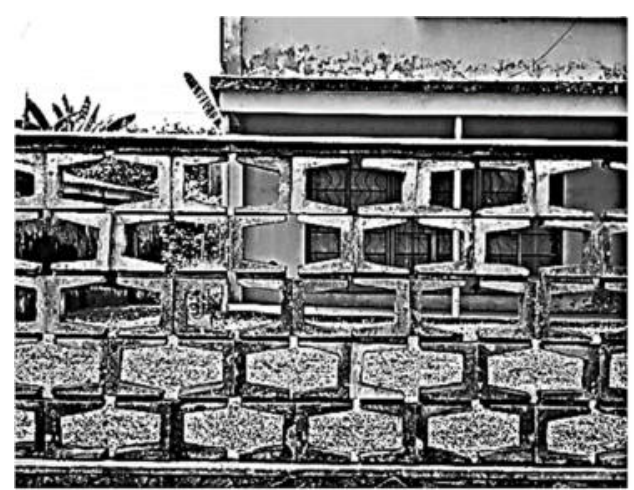

Figure 3: The use of an ornamental slab on see through top (Photo: F.M. Abejide, 2019).

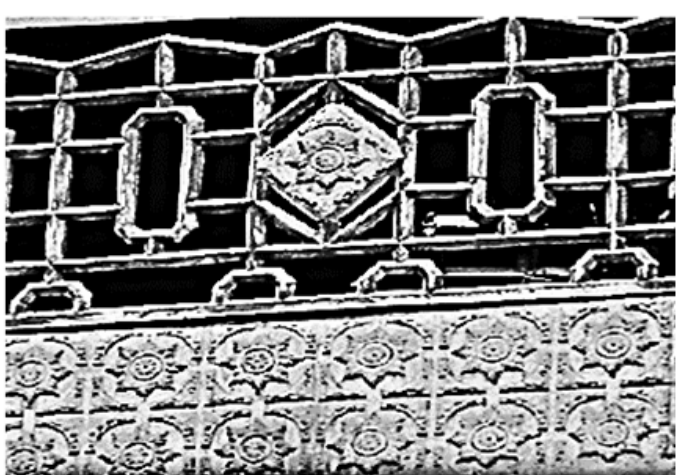

Figure 4: Fence with see through masonry blocks (Photo: F.M. Abejide, 2019).

\subsection{Fences in Ceramic Bricks}

With the establishment of ceramic bricks industries in Western Nigeria in the 1980s came various types of bricks in the walling and ornamentation of domestic building and fences in the Yoruba geographic area. These ranged from the flat hollowed 7 inches bricks with linear furrows, usually left un-plastered, to retain the linear textures and the natural red oxide colour. The joints and connection points of the bricks were also sometimes pointed (to clean off excess cement, leaving straight edges in contrasting ash colour, while some were painted in the colour of the bricks for uniformity and aesthetics. There is also flat rectangular terracotta slabs used only for decorative wall dressings. These allow creative and artistic arrangement as the Flemish bond, or the English garden bond, and sometimes crisscross placement of equal lengths of vertical and horizontal bricks. Both the bricks and perforated block provide opportunity for seeing through the fence walls.

Expansion of fences started with the use of high fortification, which became associated with associated with wealth and class distinction. The high fences sealing up the entire façade of buildings, which used to be the core target areas of ornamentation, made it difficult for ornamentations in the houses to be seen by passersby. This led to elaboration of designs on the fences, to keep up with the culture of impressing outsiders with ornamentation on buildings.

\subsection{Stucco Plastered Fence Walls}

The commonest but most varied decorative treatment of fences are in the stucco plastered walls, with forms that differ and usually more elaborate than the forms on walls of buildings. These are also in three categories: the structurally designed fences in stucco, fences decorated with stucco incisions and stucco relief ornamented fences. 6.3.1 The Structurally Designed Fences

These are the architecturally erected fences in various structural styles other than the usual rectangular continuous walls. The forms are most times part of the initial drawing or plan of buildings, erected with sandcrete blocks in desired arrangement. The aesthetics of the fences in this category are in their geometric forms such as lozenges, chevrons, curvy, pyramidal, cubic, or perpendicular shapes. There also fences in alphabetic mimesis of letters $\mathbf{b}$, $\mathbf{c}, \mathbf{d}, \mathbf{h}, \mathbf{v}, \mathbf{m}, \mathbf{n} \mathbf{L}, \mathbf{N}, \mathbf{M}$ or $\mathbf{X}$, in recurrent repeated arrangement. They sometimes have layered or serrated ends to which are affixed linear or curvilinear iron grilles.

\subsubsection{Incised Ornamented Fences in Stucco}

The incised decorations found on fences in Osogbo range from floral motifs (Figure 5), to geometrical forms such as circles, concentric circles, spirals, lozenges, polygons, cubic or rectangular shapes. Some are also mimetic of stars, crosses, and crescent with stars or moon. The incised designs on fences can be handled by masons, which make them affordable to many, hence are numerous in the city. Most of these are built with the fences or formed during plastering. 


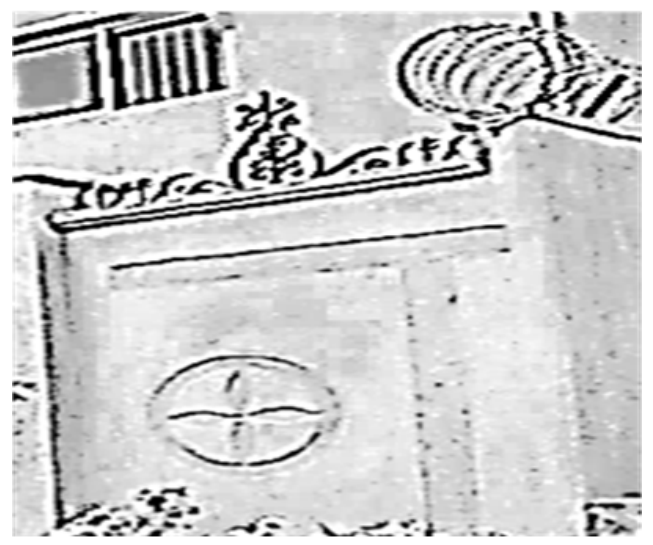

Figure 5: Fence with incised rosette design

Photo: Folúsó Abéjidé, 2019).

\subsubsection{Fences Relief Ornamentation in Stucco}

In this category are embossed forms which are most times not constructed with the walls, but are later additions ordered for decoration. They can be further categorized into geometric reliefs and fences with mimetic forms.

6.3.3.1 Fences Embellished with Geometric Reliefs

This type of fences also showcases geometrical relief decorations. They like the incised and structurally designed fences, are sometimes further affixed with linear and curvilinear irons lattices, which doubled as decorative and electro-magnetic devices for added protection.

\subsubsection{Fences Embellished with Stucco Figurative Compositions}

These are stucco fences decorated with mimetic figurative forms. The treatment of fences with symbolic compositions which may be realistic or abstracted is advancement in ornamentation in the post-modern era, emanating from the influence of the Mbabi-mbayo art workshop in Osogbo in the early1960s. They require combined services of masons and artists, hence are costlier than the former types, which make them uncommon.

Bello Gaiza Adéyemo's building, at Ògoolúwa, Òsogbo, is one of the buildings with lavishly embellished fence with multiple relief figurative ornamentations in panels (Figure 6). Embellishing the fence are forms of traditional drummers, a mosque, fishes encircling a bowl (illustrating the myth of origin of the city), the image of a hand holding the Islamic prayer beads, hands holding an Islamic slate inscribed with Arabic texts, as well as an assemblage of horns. They therefore depict traditional images alongside with Islamic religious icons. The relief panels are painted in black colour, highlighted with gold, which contrast with the colours of the fence, while vital

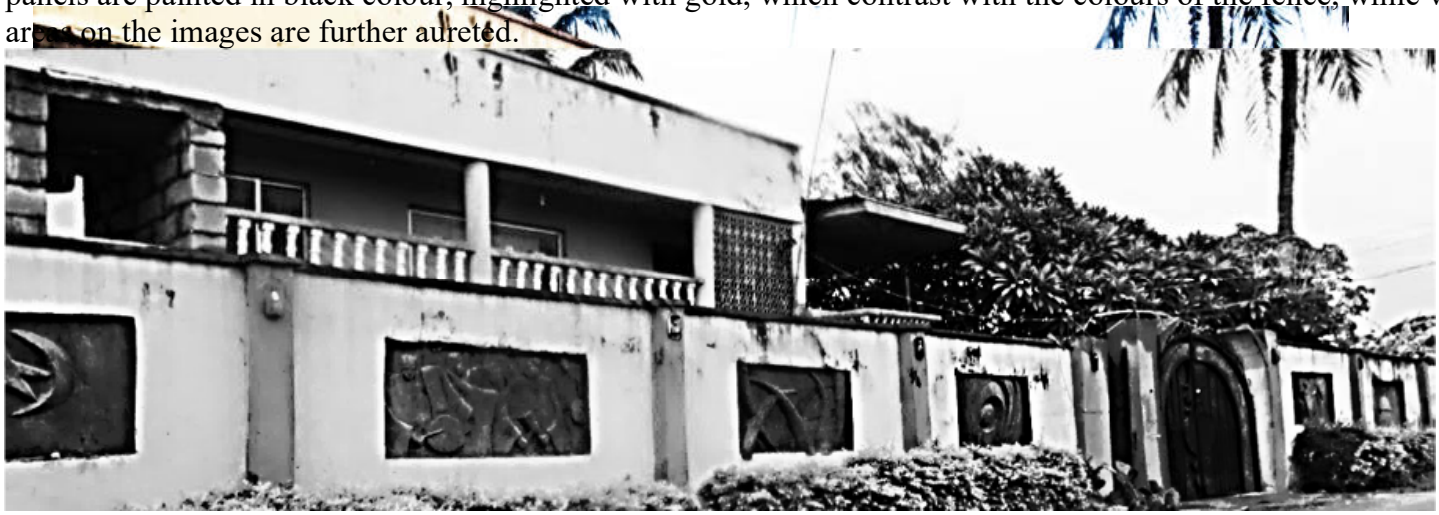

Figure 6: Fence of Bello Gaiza Adéyemo's building, Ògoolúwa, Òsogbo, ornamented with multiple panels of relief figurative compositions (Photo: Folúsó Abéjidé, 2019).

Even more entertaining are the high relief forms on the interior fence wall of Taiwo Olaniyi's building (Figure 7). It is a polychromatic painted high relief rendering of masquerades and guides, with drummers and dancers.

Another new dimension in stucco fence wall embellishment in Osogbo is the graphical projection of Islamic calligraphy in unique attractive way on fence walls. This is evident in the bold single paneled Islamic inscription embellishing the fence wall of No. 29 Murphy Street, Iwo road, Osogbo (Figure 8). However, unique to the wall reliefs in Olaniyi's building is the elaboration of both the exterior and interior fence walls, and not the external walls alone like many other buildings. The forms on this fence wall like Wenger's screens, in Ibokun road (Figure 
2), and the Islamic inscription embellishing a fence in G.R.A., Osogbo ${ }^{1}$ (Figure $10 \mathrm{a}-\mathrm{f}$ ), are in continuous narrations (one panel being a continuation of the other in successions).

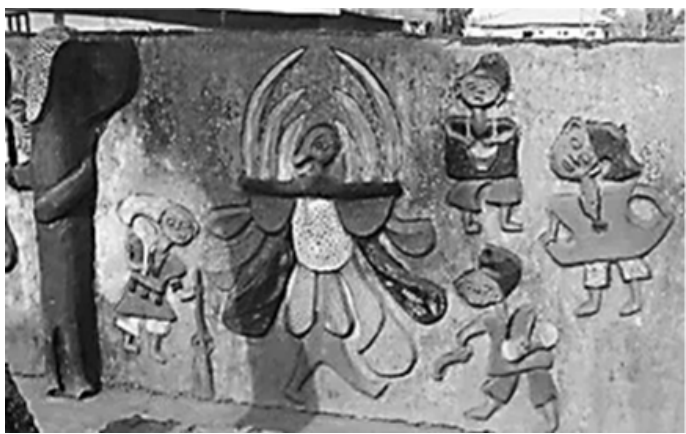

Figure 7: Masquerades and guides (atokun) embellishing Taiwo Olaniyi's inner fence wall (Photo: F.M. Abejide, 2019).

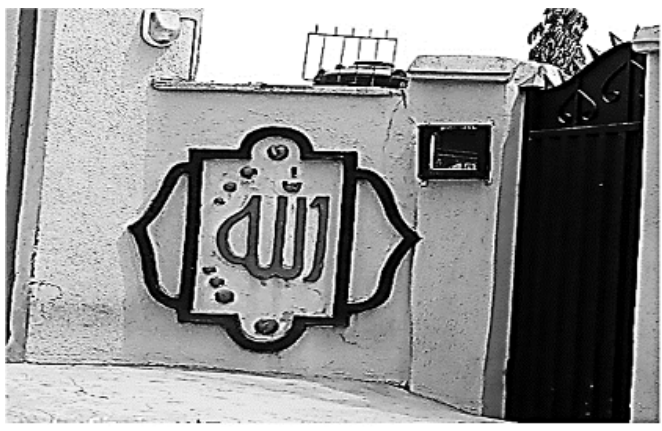

Figure 8: Embossed Islamic text on the fence wall of No. 29 Murphy Street, Iwo road, Osogbo (Photo: F.M. Abejide,2019).

6.4. Murals or Paint Embellished Fence Walls

Mural according to Folaranmi and Oyeniyi (2015:47) originates from the Latin word 'murus', meaning 'wall', affirmed to be paintings done directly on the wall or surfaces that are affixed on walls. This is corroborated by Hornby (2018:1018)'s, definition of murals as a paintings applied directly to a wall, or other large permanent surfaces. The wide uninterrupted spaces in fences make them suitable for ornamentation in murals. Mural compositions in synthetic paints was introduced in the 1970s, a progress inspired by exposure through formal art schools, the influences of cultural re-enactment in the Mbabi-mbayo workshop and late Suzanne Wenger's Sacred Art Group. Murals on these fences can be further classified into two: fences with simple forms and fences with figurative compositions in colours.

6.4.1 Fences with Simple Forms in Synthetic Colours

In this category are adornments in simple repeat patterns or portrayer of simple motifs or icons. Some of these are initially embossed before the application of colours. An example is the decoration with Islamic text on the

fence wall at No. 29 Murphy Street, Iwo road, Osogbo (Figure 8). Also in this category are painted Quranic verses based on names of Allah embellishing a fence in G.R.A, Osogbo ${ }^{1}$ (Figures 9a-f). Furthermore, there are repeat patterns achieved by covering fence walls with textured designs in thick colours applied with rollers. This yield all over patterns which vary with the designs on the roller that serves as the templates (Plate 10).

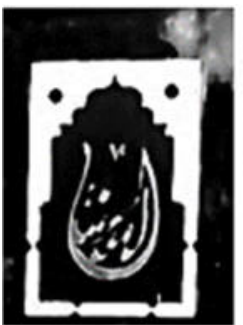

Figure 9a

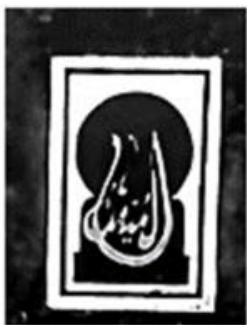

Figure $9 b$

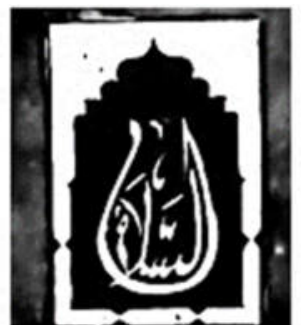

Figure 9c

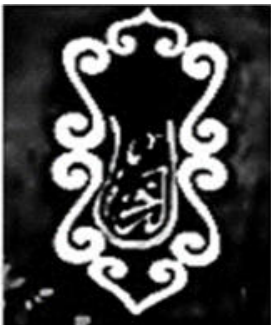

Figure 9ac

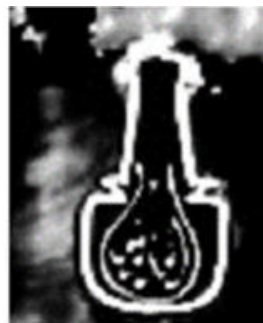

Figure 9c

Figures 9a-f: Quranic verses based on names of Allah adorning a fence in G.R.A, Osogbo (Photo: F.M. Abeiide, 2015). 


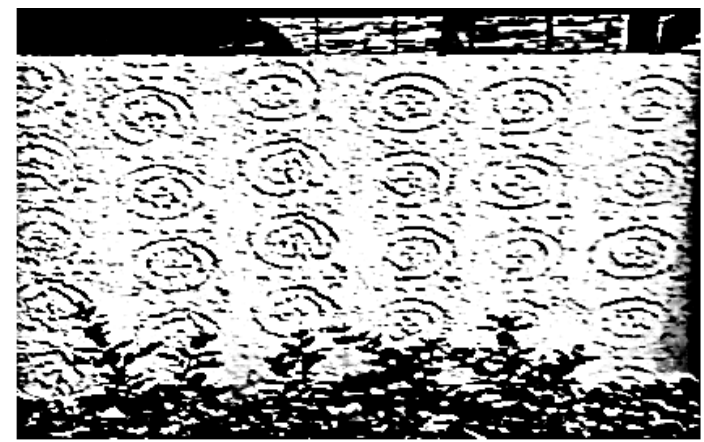

Figure 10: Fence with roller texturized repeat patterns (Photo: F.M. Abejide, 2019).

\subsubsection{Fences with figurative murals and painted reliefs}

The mural paintings in figurative compositions are symbolic forms composed with reminiscent intent. Embellishing Elebuibon's fence are figurative paintings reflective of culture of the city, one of the forms is shown in figure 11 below.

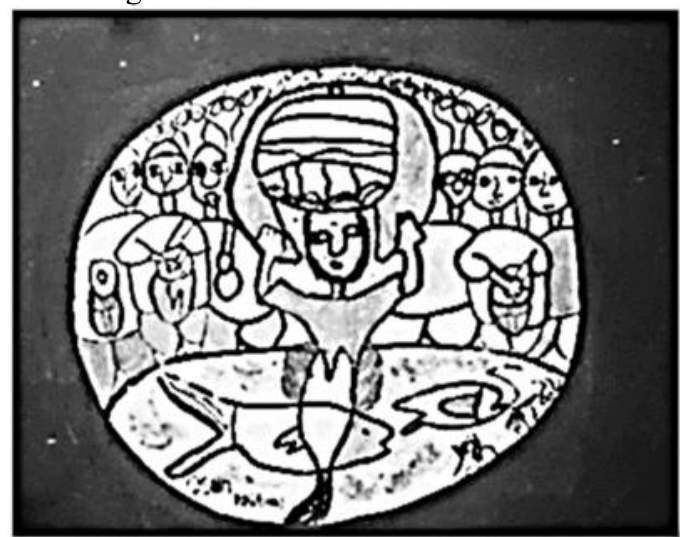

Figure 11: Fence with figurative painting

(Photo: F.M. Abejide, 2019).

Figure 12 showcases wavy texturization with stabilized earth embellishing Tayo Abiola's fence, at Ede road, Osogbo. The ornamentation on the fence is different from the forms on his building. Unlike the building in zigzag and wavy ornamentation in only two colours, the fence utilizes assorted forms in four types of soils; sand, humus, clay and laterite, which produces about six colours: white, sandy cream, light grey, ochre, light brown, and dark brown hues. This shows the freedom offered by fences, as presentation of such multiple hues on walls of building will make it look overdone and distasteful.

A close- up of the panels reveals philosophical subjects in a rich varieties of tactile textures, colours, shapes, sizes, and tones. It is also the most varied in shapes, such as circles, semi-circles, straight lines and curvatures, wavy lines and concentric circles, oval shapes, oblong, rectangles, triangles, zigzags, and wavy lines, in assorted sizes, with iconic signs against cowries. 


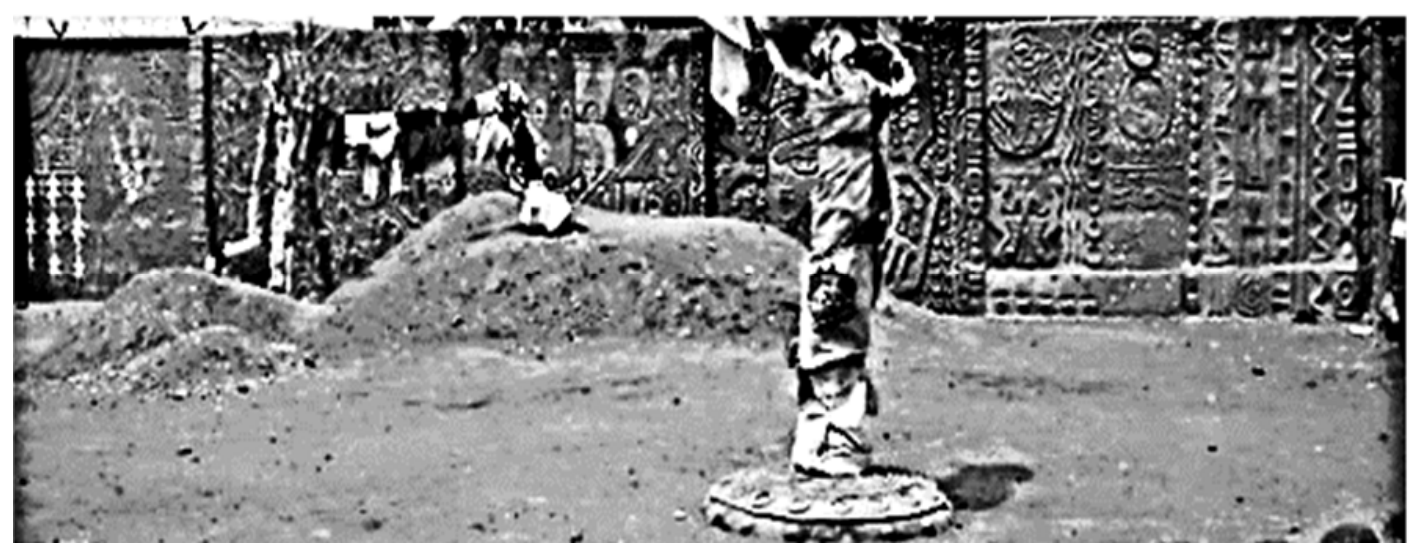

Figure 12: Multiple panelled texturised mud relief painting on Tayo Abiola's fence wall, Ofatedo, Osogbo, (Foluso Abejide, 2019).

\subsection{Fences Decorated with Contemporary add-ons}

Many kinds of polished stone -works are utilized on fence walls in the modern scenario; portions of walls are in some places treated with stones set on edge, giving a rough visual and rich tactile feel (Figure 13). There are also factory manufactured artificial tiles with stone textures, whose usage give a simulated or mimesis of stone textures, or other interesting shapes and colours to buildings. Many other add-ons are utilized in the decoration of fences , an example is the plate 14 showing the creative use of graduated triple repeated pilasters on a high fence at Adédàpò Adégòkè Street, Òròkí Estate, Òkèfíà Òsogbo.

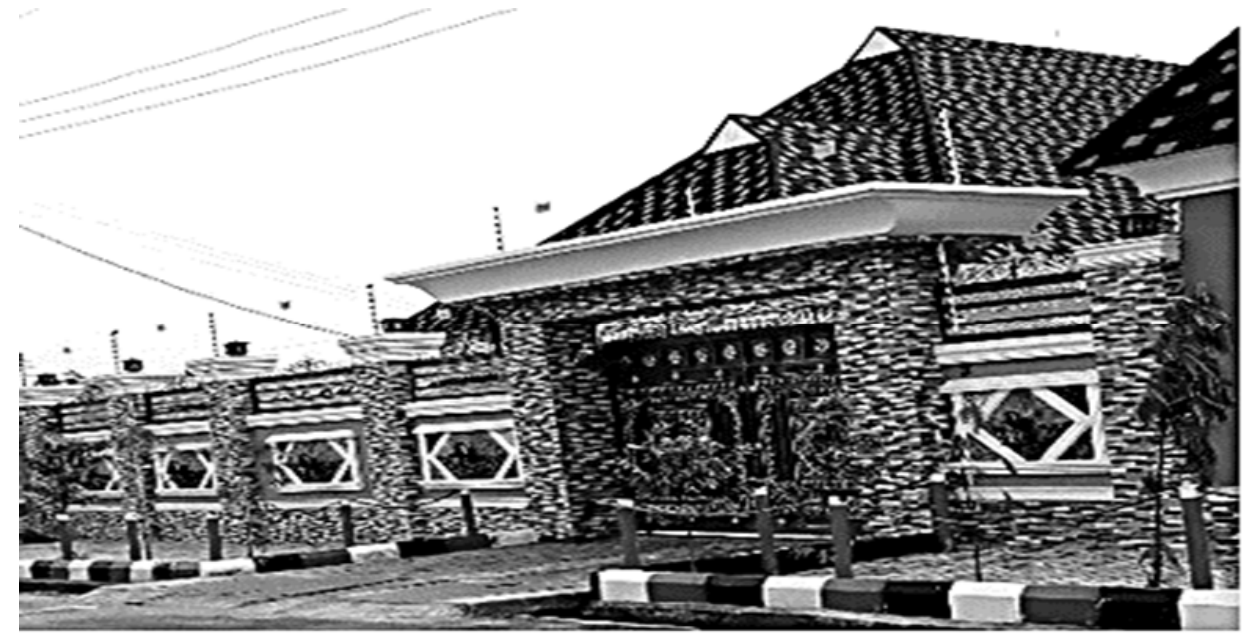

Figure 13: High fence adorned with simulated stonework (Photo: Foluso Abejide, 2019). 


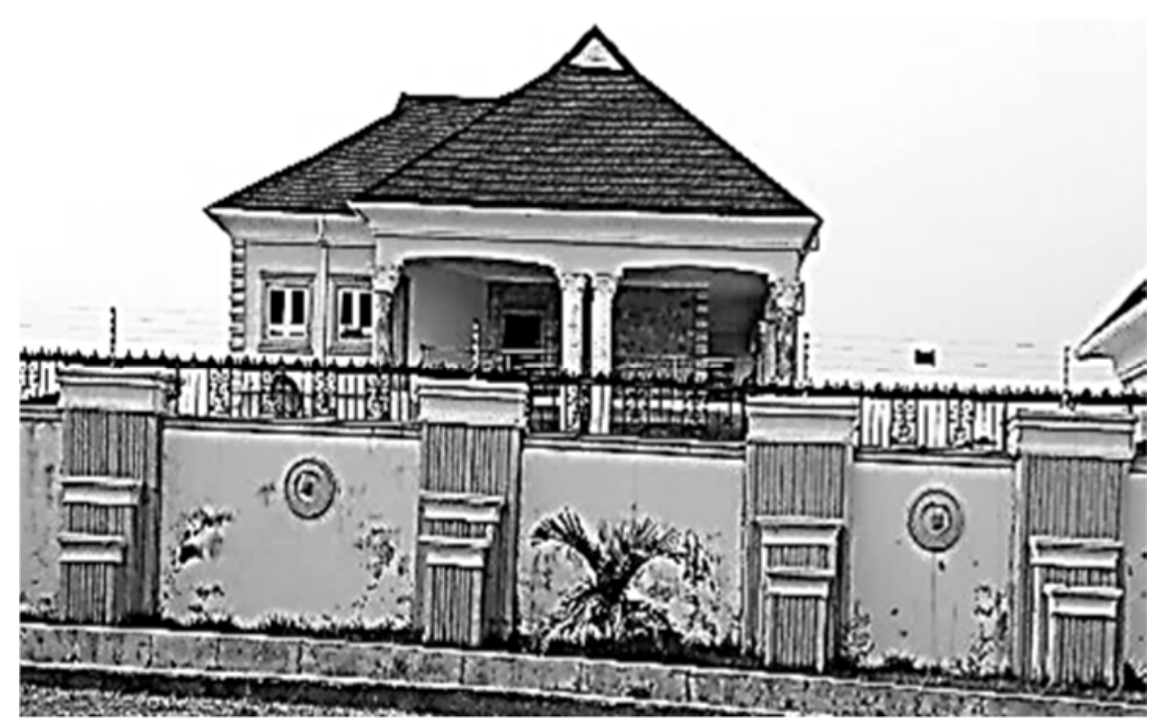

Figure 14: High fence adorned with rows of repeated triple pilasters and welded iron with tree and crown motifs (Photo: Foluso Abejide, 2019).

\section{Findings and Concluding Discussions}

Research findings reveal that fence ornamentations in Osogbo are advances in locations of ornamentation of buildings and new developments in modern Nigerian art, incited by insurgences in the country. It is discovered to have been set off from border marking with plants to low walled enclosures for Afro-Brazilian buildings, with its elaboration inspired by the Mbabi-Mbayo and Ori-olokun workshop experiments, in Ile Ife and Osogbo. It was also spurred by Suzanne Wenger's work in Osun shrine, activities of her New Sacred Art group and her innovative use of cement screens for boundary demarcation in the 1950s. Fences since evolved from the see through types in perforated masonry blocks to fortified barriers in ceramic bricks in varied artistic arrangements. Lastly there are high fences in stucco, sealing up the entire façade of buildings, which is associated with class distinction.

The high fences are discovered to provide large spaces that grew into locations for various types of ornamentation, ranging from figurative reliefs and painting in synthetic colours, mud reliefs in multiple textures and colours, modern stone walling as well as adornment with tiles, stones and pillasters. The figurative decoration transformed fences from ordinary fortified barriers into objects of communication, entertainment and cultural projection, while increasing the value of the building it is attached to. They are observed to add to the aesthetics of the environment, while providing nodes for designating areas where they are located. The study therefore reveals that Osogbo exhibits rich and divergent styles of fence embellishment in the private homes, with diverse imagery and materials, which evolve with the means of the owners. It is concluded that the art of fortification and fence ornamentation has advanced in tasteful creations, just as artists experiment with different materials, forms and styles in their efforts to attain uniqueness and identity in all aspects of Nigerian art.

\section{REFERENCES}

Abraham, R.C. (1958). Dictionary of Modern Yoruba, London University Press. 552

Anokye, P. A., Tanyeh, J.P., and Agyemang, F.S.K. (2013). The Emergence of Gated Communities in Ghana and their Implications on Urban Planning and Management Developing Country Studies, www.iiste.org ISSN 2224-607X Vol.3(14): 40-47

Atkinson, R. and Blandy, S. (2005) Introduction: international perspectives on the new enclavism and the rise of gated communities. Housing Studies 20(2): 177-186.

Fadamiro, J. A., Adedeji, J. A., and Daisiowa Y.M. (2015). Residential Fencing and House Gating: An Overview of Social Inequality and Urban Insecurity in Ilorin, Nigeria, The Proceedings of Environmental Design and Management International Conference, Obafemi Awolowo University, Ile-Ife. Vol (5): 483-492.

Folaranmi, S.A. and Oyeniyi, O. (2015). Changing The Face of The Built Environment Through Murals: The IleIfe Example. Proceedings of Environmental Design and Management International Conference, Obafemi Awolowo University, Ile-Ife. 47-56.

Ilesanmi, A. (2012). The roots and fruits of gated communities in Lagos, Nigeria: social sustainability or segregation? Proceeding on Sustainable Futures: Architecture and Urbanism in the Global South Kampala, Uganda. 105-112. Accessed on $17^{\text {th }}$ August, 2019. 
Landman, K. and Schönteich, M. (2002). Urban Fortresses: Gated communities as a reaction to crime. in African Security Review, Vol 11(4). pp 71-85. Retrieved on 12th of May, 2019 from https://doi.org/10.1080/10246029.2002.962814

Marenin, O. and Reisig, M. D. (1995): “A general Theory of Crime and Patterns of Crime in Nigeria: an Exploration of methodological Assumptions", in Journal of Criminal Justice, Department of Political Science, Washington State University No. 6, Vol. 23. (503) Retrieved on the 6th of December, 2018 from https://www.sciencedirect.com/science/article/pii/0047235295000429

Obijiofor, L. (2008). Nigeria, Good Times and Bad Times, Vanguard, July 18, accessed on the 22 ${ }^{\text {nd }}$ April, 2018.

Osasona, C.O. (2005). Ornamentation in Yoruba folk Architecture, Ibadan: Book builders.

Osasona, C.O. (2006). The Nigerian Fence Culture. University of Nairobi Africa Habitat Review Journal, Vol. 1(1).35-46.

Roitman, S. (2010). Gated communities: definitions, causes and consequences Proceedings of the Institution of Civil Engineers Urban Design and Planning. 31-38 doi: 10.1680/udap.2010.163.1.31 Paper 900037.

Siollum, M. (2009). Oil, Politics and Violence: Nigerian Military Coup Culture (1966-1976) Algora publishing Co, New York. 168. Retrieved on the 6th of December, 2018 from www. algora.com.

Torrington, D. (2013). The Effects of Private Walls on Relationships Across Class and Race in the New South Africa. A thesis submitted in partial fulfillment of the requirement for the Degree of Bachelor of Arts in Political Science with Distinction. The University of Pennsylvania Philadelphia, PA.

Manzi, T. and Smith-Bowers, B. (2005). Gated Communities as Club Goods: Segregation or Social Cohesion? Housing Studies. 20(2):pp.345-359. Retrieved on 12th of May, 2018 from https://doi.org/10.1080/0267303042000331817

Notes

1. This is an unnumbered new area as at the time this research is been conducted 